\title{
Strategies of fertigation with saline water for growing cucumber in a greenhouse
}

Francisco de A. de Oliveira ${ }^{1}$, Maria L. de Souza Neta ${ }^{1}$, Neyton de O. Miranda ${ }^{1}$, Antônia A. T. Souza ${ }^{1}$, Mychelle K. T. de Oliveira $^{1}$ \& Dennis D. A. da Silva ${ }^{1}$

${ }^{1}$ Universidade Federal Rural do Semi-Árido/Centro de Ciências Agrárias. Mossoró, RN. E-mail: thikaoamigao@ufersa.edu.br (Corresponding author); lilia.agronomia@hotmail.com; neyton@ufersa.edu.br; adailhatorres@hotmail.com; mymykar@gmail.com; dnis.almeida@hotmail.com

Key words:

Cucumis sativus

salinity

split root system

\begin{abstract}
A B S T R A C T
The objective of this study was to evaluate the use of saline water to grow cucumbers cultivated in substrate composed of coconut fiber and washed fine sand (1:1) and submitted to splitroot system. The experimental design was completely randomized, with eight treatments and four replicates. Treatments consisted of different fertigation managements, comprising two nutrient solutions of different electrical conductivities (1.65 and $\left.6.25 \mathrm{dS} \mathrm{m}^{-1}\right)$, applied in a continuous or alternated way, with splitting or not of the root system (S/S). Growth and yield variables were evaluated. The use of water with electrical conductivity of $6.25 \mathrm{dS} \mathrm{m}^{-1}$ to prepare the nutrient solution caused significant reduction in all variables of cucumber growth and production. Adoption of split-root system with simultaneous application of the two water types increased cucumber tolerance to salinity.
\end{abstract}

\section{Estratégias de fertirrigação com água salina na cultura do pepino em ambiente protegido}

\begin{abstract}
R E S U M O
O objetivo deste trabalho foi avaliar o uso de água salina na cultura do pepineiro cultivado com substrato composto por fibra de coco e areia fina lavada (1:1) utilizando o método de divisão do sistema radicular. $\mathrm{O}$ experimento foi realizado com o uso do delineamento inteiramente casualizado, com oito tratamentos e quatro repetições. Os tratamentos foram obtidos pela combinação de dois níveis de salinidade da solução nutritiva (1,65 e 6,25 dS m-1), com ou sem divisão do sistema radicular (S/S). Foram avaliadas as variáveis de crescimento e de rendimento. $\mathrm{O}$ uso de água com salinidade de $6,25 \mathrm{dS} \mathrm{m}^{-1}$ no preparo da solução nutritiva provoca redução significativa em todas as variáveis de crescimento e de produção do pepineiro. O uso do sistema de divisão das raízes com aplicação de dois tipos de água simultaneamente, aumentou a tolerância do pepineiro à salinidade.
\end{abstract}

\section{Palavras-chave:}

salinidade

divisão do sistema radicular 


\section{INTRODUCTION}

Cucumber (Cucumis sativus), belonging to the Cucurbitaceae family, stands out among the main vegetables produced and consumed in Brazil. This crop is classified as moderately sensitive to salinity, exhibiting threshold salinity of $2.5 \mathrm{dS} \mathrm{m} \mathrm{m}^{-1}$ of the saturation extract and relative yield loss of $13 \%$ per unit increase in salinity (Maas \& Hoffman, 1977).

The literature has various studies on the cucumber crop under salt stress (Santana et al., 2010; Medeiros et al., 2009; Colla et al., 2012) and in all of them the salt stress caused reduction in crop yield. Thus, it is evident the need for studies to reduce the deleterious effect of salinity on the crop.

Cultivation in inert substrate using split-root system into two parts has been adopted to save water and improve the quality of various vegetables, such as tomato (Sun et al., 2014) and pepper (Shao et al., 2008).

This cultivation system allows the non-uniform of saline water, so that each portion of the root system can be irrigated with one type of water (Koushafar et al., 2011; Guedes et al., 2015). According to Flores et al. (2002), when half of the root system was treated with salinity, water absorption decreased in the treated part, but there was a compensatory increase in water absorption through the non-treated part, reducing the deleterious effect of salinity.

In the Brazilian literature, there are few studies on this topic, such as that developed by Guedes et al. (2015) with the cherry tomato crop; these authors observed that the split-root system can be a viable alternative for the use of saline water in irrigation. Given the above, the present study aimed to evaluate the effect of using saline water on growth and production variables of cucumber, adopting the split-root system.

\section{Material AND Methods}

The research was carried out in a greenhouse from April to July 2015, at the Federal Rural University of the Semi-Arid Region (UFERSA), Mossoró-RN (5 11' S; 37² 20' W, 18 m of altitude). The greenhouse has a 10 -mm-thicck, transparent, low-density polyethylene cover, treated against the action of ultraviolet rays with an arched shape, $6.40 \mathrm{~m}$ wide and $22.5 \mathrm{~m}$ long. Side and front walls are made of anti-aphid screen and 0.30-m-high bottom part made of reinforced concrete.

The experiment was conducted in a completely randomized design, with eight treatments and four replicates, and the experimental unit was represented by two pots with capacity for $10 \mathrm{~L}$, with one plant each, resulting in 64 plants. Treatments were obtained through the combination of two salinity levels of the nutrient solution (S1-1.65 and S2-6.15 dS m-1), with or without split-root system, as described below:

T1 - Fertigation using S1 nutrient solution during the entire cycle;

T2 - Fertigation using S2 nutrient solution during the entire cycle;

T3 - Fertigation using both nutrient solutions alternately (S1 - 5 days after transplanting (DAT) to 30 DAT and S2 - 31 DAT until the end of the experiment - 75 DAT);
T4 - Fertigation using both nutrient solutions alternately (S2 from 5 to 30 DAT and S1 from 31 DAT until the end of the experiment - $75 \mathrm{DAT}$ );

T5 - Fertigation using both nutrient solutions, with splitroot system and without alternation during the cycle;

T6 - Fertigation using both nutrient solutions, with splitroot system and with alternation (part of the roots was initially irrigated with S1 from 5 DAT to 30 DAT, followed by S2 from 31 DAT until the end of the experiment - 75 DAT); part of the plants irrigated with S2 from 5 to $30 \mathrm{DAT}$, followed by S1 from 31 DAT until the end of the experiment - 75 DAT);

T7 - Fertigation using both nutrient solutions, with splitroot system and with alternation (part of the plants was initially irrigated with S1 from 5 to 25 DAT, followed by S2 from 26 to $46 \mathrm{DAT}$, followed by S1 from 46 DAT until the end of the experiment - 75 DAT);

T8 - Fertigation using both nutrient solutions, with splitroot system and with alternation (part of the plants was initially irrigated with S2 from 5 to 25 DAT, followed by S1 from 26 to 46 DAT, followed by S2 from 46 DAT until the end of the experiment - 75 DAT);

For the treatments T5, T6, T7 and T8, the root system was split using plastic film and adhesive tape. During transplantation, the soil clods around the roots of all seedlings were broken, in such a way not to damage the root system.

The pots were arranged in 8 rows containing 8 pots each, distributed at the spacing of $1.0 \mathrm{~m}$ between rows and $0.60 \mathrm{~m}$ between plants in the row.

The experiment used cucumber seedlings, cv. Aodai, produced on expanded polystyrene (Styrofoam ${ }^{\star}$ ) trays with capacity for 128 cells containing substrate of coconut fiber and earthworm humus (1:1 v:v). Transplanting was performed using one seedling per pot, when the seedlings showed two true leaves (12 days after sowing).

Plants were vertically trained with the aid of a string, conducted with one stake per plant without removing the lateral branches (Santi et al., 2013), performing the other cultivation practices according to the necessity.

In the first five days after transplanting, all treatments were irrigated using water with lower salinity level, to promote a uniform development of the seedlings. From the fifth day on after transplanting, the seedlings started to receive the salinity levels according to the established treatments.

Irrigations were applied using two identical systems for both salinity levels, and each system was composed of a PVC tank (500 L), a self-venting circulation electric pump, Metalcorte/ Eberle, model EBD250076 (actuated by a monophasic motor, $210-\mathrm{V}$ tension, $60-\mathrm{Hz}$ frequency, normally used in washing machines), 16-mm-diameter lateral lines and microtube emitters, with mean flow rate of $2.5 \mathrm{~L} \mathrm{~h}^{-1}$.

Water with salinity of $5.0 \mathrm{ds} \mathrm{m}^{-1}$ was obtained through the dissolution of sodium chloride in water collected in the UFERSA supply system. All irrigations were applied using nutrient solution (Bezerra Neto \& Barreto, 2012), containing the following concentration of fertilizers, in $\mathrm{g} 1.000 \mathrm{~L}^{-1}$ : calcium nitrate (960); potassium nitrate (485); potassium phosphate (245); magnesium sulfate (418); manganese sulfate (4.23); Borax (1.90); zinc sulfate (1.15); copper sulfate (0.12); sodium 
molybdate (0.12). Besides these fertilizers, $800 \mathrm{~mL}$ of Fe-EDTA (38.5 $\left.\mathrm{g} \mathrm{L}^{-1}\right)$ were used for every $1.000 \mathrm{~L}$ of nutrient solution. After preparation, the nutrient solutions showed electrical

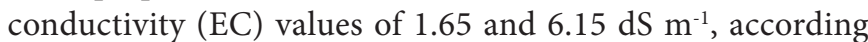
to the utilized solutions.

During the experiment, five fruit harvests were performed and the following variables were evaluated: number of fruits, length, diameter, fresh weight and production per plant. At the end of the experiment (75 DAT), plants were collected and the following growth variables were evaluated: number of leaves, leaf area, leaf dry matter, stem dry matter, fruit dry matter and shoot dry matter.

To obtain the dry matter, plants were divided into leaves and stem, placed in paper bags and dried in forced-air oven at $65{ }^{\circ} \mathrm{C}$. Similarly, after each harvest, fruits were evaluated and dried in the oven, following the same procedure used for drying and, subsequently, weighed on analytical scale $(0.01 \mathrm{~g})$.

The data were subjected to analysis of variance and means were compared by Tukey test at 0.05 probability level, using the statistical program Sisvar 5.1 (Ferreira, 2011).

\section{Results AND Discussion}

The different fertigation managements significantly affected all evaluated growth variables at 0.01 probability level (Table 1 ).

Stem diameter (SD) was reduced by the exclusive use of saline water during the entire cycle (T2) and when the most saline solution was used in the first 30 days (T4). The other fertigation managements using saline solution did not differ from the exclusive management with solution of lowest salinity (T1) (Table 1).

Salinity effect on cucumber stem diameter has been little studied, but the few reports demonstrate that under salt stress conditions the plants show reduction of this variable (Santana et al., 2010; Peykanpour et al., 2015).

Number of leaves and leaf area exhibited, in a certain way, similar responses to the studied treatments, and the lowest values were obtained when the most saline was used during the entire cycle (T2), in the first stage of the cycle (T4) and in three periods of application (T8). Comparing the results obtained in these treatments with those obtained using only solution of lowest salinity (T1), there were reductions of 37.8, 12.9 and $31.2 \%$ in the number of leaves for $\mathrm{T} 2, \mathrm{~T} 4$ and $\mathrm{T} 8$, respectively. For leaf area, the reductions were $49.6 \%$ in $\mathrm{T} 2 ; 40.9 \%$ in $\mathrm{T} 4$ and $28.3 \%$ in $\mathrm{T} 8$, in comparison to the treatment $\mathrm{T} 1$ (Table 1 ).

Other authors have already demonstrated that leaves are the plant organs most affected by salt stress, both in the production of new leaves and development of leaf blade (Oliveira et al., 2014). According to Tester \& Davenport (2003), the smaller leaf area of plants under salt stress reflects the effect of the osmotic potential of the soil solution inhibiting water absorption by the plant; additionally, the reduction in leaf area is possibly related to one of the adaptive mechanisms of the plant to salt stress and to the decrease in the transpiring surface.

There was also significant effect of the treatments on the variables related to dry matter accumulation and, in general, plants fertigated with solution of highest salinity during the entire cycle (T2) showed the lowest values, with losses of 43.4, 47.7, 53.6 and $48.1 \%$ for stem dry matter (StDM), leaf dry matter (LDM), fruit dry matter (FDM) and shoot dry matter (StDM), respectively, in comparison to the values obtained in plants fertigated only with the least saline solution during the entire cycle (T1) (Table 1).

There were also significant reductions in other treatments using nutrient solution of highest salinity. In these cases, there were reductions in SDM of 23.5 and 33.1\% in the treatments T4 and T5, respectively, which used the most saline solution in the first stage of the crop. For LDM, besides T2, there were reductions of 26.2 and $29.9 \%$ in the treatments $\mathrm{T} 4$ and $\mathrm{T} 8$, respectively. The greater reduction obtained in $\mathrm{T} 8$ occurred due to the use of nutrient solution with highest salinity in two stages of the experiments (Table 1).

Considering the treatments with split-root system (T5 and T6), both treatments promoted water and nutritional availability, which favor plant development, showing for all variables (except StDM in T5) (Table 1), values that did not differ statistically from T1. These results are similar, in part, to those obtained by Attia et al. (2009) and Kong et al. (2012), working with peas and cotton crops, respectively. These authors observed that, when plants were cultivated in split-root system for two salinity levels, there was greater water absorption in the portion of the roots under lower salinity, with a compensation

Table 1. Mean values for stem diameter (SD), number of leaves (NL), leaf area (LA), stem dry matter (StDM), leaf dry matter (LDM), fruit dry matter (FDM) and shoot dry matter (ShDM) in cucumber plants subjected to different fertigation managements using saline solution

\begin{tabular}{|c|c|c|c|c|c|c|c|c|}
\hline \multirow{2}{*}{$\begin{array}{l}\text { Source } \\
\text { of variation }\end{array}$} & \multirow{2}{*}{ DF } & \multicolumn{7}{|c|}{ Mean square } \\
\hline & & SD & NL & LA & StDM & LDM & FDM & ShDM \\
\hline Treatments & 7 & 6.81 & 2422.66 ** & $92218279.51^{\star \star}$ & $599.93^{\star *}$ & 1558.55 & $1619.21 * *$ & 8485.24 ** \\
\hline Residual & 24 & 1.12 & 658.53 & 7486427.50 & 130.58 & 103.85 & 157.86 & 436.32 \\
\hline CV & & 9.13 & 21.69 & 14.49 & 16.69 & 12.48 & 16.56 & 9.24 \\
\hline \multirow{2}{*}{\multicolumn{2}{|c|}{ Treatments ${ }^{\#}$}} & SD & $\overline{N L}$ & $\overline{L A}$ & StDM & LDM & FDM & ShDM \\
\hline & & $(\mathrm{mm})$ & (unit) & $\left(\mathrm{cm}^{2}\right.$ plant $\left.^{-1}\right)$ & \multicolumn{4}{|c|}{ (g plant $\left.^{-1}\right)$} \\
\hline T1 & & $11.3 a b^{\star}$ & $127.0 \mathrm{ab}$ & $23217.6 a b$ & $83.4 \mathrm{a}$ & $95.7 \mathrm{ab}$ & $80.7 \mathrm{ab}$ & $259.8 a b$ \\
\hline T2 & & $9.7 \mathrm{c}$ & $79.0 \mathrm{~b}$ & $11694.9 d$ & $47.2 \mathrm{C}$ & $50.2 d$ & $37.4 \mathrm{C}$ & $134.9 \mathrm{~d}$ \\
\hline T3 & & $12.9 \mathrm{ab}$ & $132.3 \mathrm{ab}$ & $24965.2 \mathrm{a}$ & $80.7 \mathrm{ab}$ & $114.4 \mathrm{a}$ & $89.9 \mathrm{a}$ & $285.0 \mathrm{a}$ \\
\hline T4 & & $10.8 \mathrm{bc}$ & $109.3 \mathrm{ab}$ & $13715.6 \mathrm{~cd}$ & $63.8 \mathrm{abc}$ & $70.6 \mathrm{~cd}$ & $54.1 \mathrm{bc}$ & $188.8 \mathrm{c}$ \\
\hline T5 & & $12.4 \mathrm{ab}$ & $124.0 \mathrm{ab}$ & $23569.3 \mathrm{ab}$ & 55.8 bc & 90.5 bc & $81.7 \mathrm{ab}$ & 227.9 bc \\
\hline T6 & & $11.6 \mathrm{ab}$ & $148.7 \mathrm{a}$ & $18882.1 \mathrm{abc}$ & 70.8 abc & 87.7 bc & $86.5 \mathrm{a}$ & $245.0 \mathrm{ab}$ \\
\hline $\mathrm{T} 7$ & & $11.6 \mathrm{ab}$ & $139.0 \mathrm{ab}$ & 18332.4 bc & 73.2 abc & 77.1 bc & $77.8 \mathrm{ab}$ & 228.1 bc \\
\hline T8 & & $13.7 \mathrm{a}$ & $87.3 \mathrm{~b}$ & $16654.6 \mathrm{~cd}$ & $72.7 \mathrm{abc}$ & $67.1 \mathrm{~cd}$ & $98.5 \mathrm{a}$ & $238.3 \mathrm{ab}$ \\
\hline
\end{tabular}

\# For details of treatments see Material and Methods

** Significant at 0.05 probability level; Means followed by the same letter in the column do not differ significantly by Tukey test at 0.05 probability level 
Table 2. Mean values for number of fruits (NF), fruit length (FL), fruit diameter (FD), fruit fresh weight (FFW) and production (PROD) of cucumber subjected to different fertigation managements using saline solution

\begin{tabular}{|c|c|c|c|c|c|c|}
\hline \multirow{2}{*}{$\begin{array}{c}\text { Source } \\
\text { of variation }\end{array}$} & \multirow{2}{*}{ DF } & \multicolumn{5}{|c|}{ Mean square } \\
\hline & & NF & $\overline{F L}$ & FD & FFW & PROD \\
\hline Treatments & 7 & $12.59 \star \star$ & $14.84^{\star \star}$ & $0.91 * \star$ & $5646.07 * *$ & $2001553.72^{\star \star}$ \\
\hline Residual & 24 & 0.78 & 1.63 & 0.16 & 846.73 & 170779.72 \\
\hline CV & & 11.13 & 9.16 & 8.53 & 10.74 & 18.69 \\
\hline \multirow{2}{*}{ Treatments $\#$} & & NF & $\mathrm{FL}$ & FD & FFW & PROD \\
\hline & & (unit) & \multicolumn{2}{|c|}{ (cm) } & ( $g$ fruit $\left.^{-1}\right)$ & $\left(\right.$ g plant $\left.^{-1}\right)$ \\
\hline $\mathrm{T} 1$ & & $9.6 \mathrm{a}$ & $20.4 \mathrm{a}$ & $5.2 \mathrm{a}$ & $309.6 \mathrm{a}$ & $2989.1 \mathrm{a}$ \\
\hline T2 & & $4.6 \mathrm{c}$ & $14.9 \mathrm{c}$ & $3.7 \mathrm{~b}$ & $199.6 \mathrm{C}$ & $929.8 \mathrm{C}$ \\
\hline T3 & & $7.8 \mathrm{ab}$ & $18.8 \mathrm{ab}$ & $4.3 \mathrm{ab}$ & $273.2 \mathrm{ab}$ & $2139.9 \mathrm{ab}$ \\
\hline T4 & & $6.1 \mathrm{bc}$ & 16.1 bc & $4.7 \mathrm{a}$ & 240.2 bc & $1461.8 \mathrm{bc}$ \\
\hline T5 & & $8.0 a b$ & $19.6 \mathrm{a}$ & $4.8 \mathrm{a}$ & $299.7 a b$ & $2415.1 \mathrm{ab}$ \\
\hline T6 & & $8.6 \mathrm{a}$ & $19.1 \mathrm{a}$ & $4.8 \mathrm{a}$ & $278.0 a b$ & $2427.6 a b$ \\
\hline $\mathrm{T} 7$ & & $9.1 \mathrm{a}$ & $18.1 \mathrm{ab}$ & $5.1 \mathrm{a}$ & $259.2 \mathrm{abc}$ & $2350.8 \mathrm{ab}$ \\
\hline T8 & & $9.5 \mathrm{a}$ & $19.8 \mathrm{a}$ & $5.0 \mathrm{a}$ & $307.5 \mathrm{ab}$ & $2973.6 \mathrm{a}$ \\
\hline
\end{tabular}

\# For details of treatments see Material and Methods

** Significant at 0.05 probability level; Means followed by the same letter in the column do not differ significantly by Tukey test at 0.05 probability level

of the osmotic stress occurred in the portion of roots under salt stress (Flores et al., 2002).

As observed for growth variables, there was also significant effect $(\mathrm{p}<0.01)$ for all yield variables (Table 2$)$.

The number of fruits per plant was significantly affected by the treatments, especially T1, T6, T7 and T8, which showed the highest values, despite not differing from $\mathrm{T} 3$ and $\mathrm{T} 5$, while T2 (irrigation with only saline water during the entire cycle) promoted lower number of fruits, despite not differing statistically from T4. Comparing the number of fruits obtained in plants subjected to the lowest salinity (T1) with the other treatments, the highest reductions occurred in the treatments $\mathrm{T} 2$ and T3, with losses of 51.8 and $37.3 \%$, respectively (Table 2).

The lowest number of fruits obtained in T2 was already expected because of the accumulation of salts in the substrate, due to the use of nutrient solution with high salinity level during the entire cycle, a fact that has already been observed by other authors (Colla et al., 2012; Medeiros et al., 2009; Santana et al., 2010; Abu-Zinada, 2015).

The reduction in the number of fruits in plants subjected to stress results from, among other factors, the greater abortion of flowers, caused by the decrease in the transport of soluble carbohydrates from the leaves to the flowers, thus reducing pollen viability (Ghanem et al., 2009). Still according to these authors, the effect of salt stress on flower abortion is more evident when the stress is applied at the beginning of the flowering, which can be observed in plants subjected to the treatment $\mathrm{T} 4$ (use of saline solution from transplanting to 30 days)

Fruit length was also affected by the treatments, with similar response to that of number of fruits. The highest values occurred in the treatments $\mathrm{T} 1, \mathrm{~T} 5, \mathrm{~T} 6$ and $\mathrm{T} 8$, although they did not differ from T3 and T7; on the other hand, the treatments $\mathrm{T} 2$ and $\mathrm{T} 4$ stood out for having fruits with shortest length, with reductions of 27.2 and $20.9 \%$, respectively, in comparison to T1 (Table 2).

The variable fruit diameter (FD) showed lower variation between the treatments in comparison to those previously presented (NF and FL), and the treatments $\mathrm{T} 2$ and $\mathrm{T} 3$ showed lower values (Table 2). Negative effect of salinity on the variables related to cucumber fruit size was also reported by other authors (Alsadon et al., 2006).

Regarding fruit fresh weight (Table 2), as observed for the other variables previously mentioned, plants fertigated with saline water during the entire cycle (T2) or in the first stage of the crop (T4) had fruits with lower fresh weight, following the effect observed for fruit diameter, with values lower than 35.5 and $22.4 \%$, respectively, in relation to the values obtained in plants fertigated during the entire cycle with solution of lowest salinity (T1).

Still regarding the variable fruit fresh weight, there was no significant difference between the other treatments (T3, T5, T6, $\mathrm{T} 7$ and $\mathrm{T} 8$ ) and $\mathrm{T} 1$, indicating that the use of saline solution at the final stage (T3), in two stages (T7 and T8) or with splitroot system (T5 and T6) does not reduce fruit weight (Table 2).

Reduction in cucumber fruit fresh weight in response to salinity was also reported by Abu-Zinada (2015), who also observed that the exclusive use of saline water reduces fruit fresh weight, and the salinity effect was reduced when saline was used only after anthesis. Alsadon et al. (2006) observed fruits with lower fresh weight in plants irrigated with saline water during the entire cycle or in the first stage of the crop, as observed in the present study (T2 and T4).

Lastly, as observed for most of the analyzed variables, the use of saline water during the entire cycle (T2) or during the first stage of the crop (T4) led to lower fruit production, whose values were lower than 68.9 and $51.1 \%$, respectively, in relation to the production obtained in plants subjected to the lowest salinity during the entire cycle (T1) (Table 2).

The results of the present study corroborate those found by Sonneveld \& Kreij (1999), who evaluated the technology of splitting cucumber root system and observed that plants subjected to salt stress in only half of the roots did not differ in the production of fruits of plants maintained with low salinity.

Thus, given the presented results and in agreement with the literature, the use of low- and high-salinity water simultaneously, with split-root system, can be a viable alternative for the conditions in which the rural producer has availability of both sources of water, especially in protected cultivation using substrate maintained in containers (Guedes et al., 2015), or in hydroponics (Mulholland et al., 2002).

\section{Conclusions}

1. The use of water with salinity of $5.0 \mathrm{dS} \mathrm{m}^{-1}$ to prepare the nutrient solution causes significant reduction in all growth and production variables of cucumber. 
2. The use of split-root system with application of two types of water simultaneously increased cucumber tolerance to salinity.

\section{Literature Cited}

Abu-Zinada, I. A. Effect of salinity levels and application stage on cucumber and soil under greenhouse condition. International Journal of Agriculture and Crop Sciences, v.8, p.73-80, 2015.

Alsadon, A.; Wahb-Allah, M. A.; Khalil, S. O. Growth, yield and quality of three greenhouse cucumber cultivars in relation to two types of water applied at different growth stages. Journal of King Saud University, v.18, p.89-102, 2006.

Attia, H.; Nouaili, S.; Soltani, A.; Lachaâl, M. Comparison of the responses to $\mathrm{NaCl}$ stress of two pea cultivars using split-root system. Scientia Horticulturae, v.123, p.164-169, 2009. http:// dx.doi.org/10.1016/j.scienta.2009.09.002

Bezerra Neto, E.; Barreto, L. P. As técnicas da hidroponia. Anais da Academia Pernambucana de Ciência Agronômica, v.8/9, p.107137, 2012.

Colla, G.; Rouphanel, Y.; Rea, E.; Cardarelli, M. Grafting cucumber plants enhance tolerance to sodium chloride and sulfate salinization. Scientia Horticulturae, v.135, p.177-185, 2012. http:// dx.doi.org/10.1016/j.scienta.2011.11.023

Ferreira, D. F. Sisvar: A computer statistical analysis system. Ciência e Agrotecnologia, v.35, p.1039-1042, 2011. http://dx.doi. org/10.1590/S1413-70542011000600001

Flores, P.; Botella, M. A.; Martínez, V.; Cerdá, A. Response to salinity of tomato seedlings with a split-root system: Nitrate uptake and reduction. Journal of Plant Nutrition, v.25, p.177-187, 2002. http:// dx.doi.org/10.1081/PLN-100108789

Ghanem, M. E.; Elteren, J. van; Albacete, A.; Quinet, M.; MartínezAndújar, C.; Kinet, J. M.; Pérez-Alfocea, F.; Lutts, S. Impact $f$ salinity on early reproductive physiology of tomato (Solanum lycopersicum) in relation to a heterogeneous distribution of toxic ions in flowers organs. Functional Plant Biology, v.36, p.125-136, 2009. http://dx.doi.org/10.1071/FP08256

Guedes, R. A. A.; Oliveira, F. de A. de; Alves, R. de C.; Medeiros, A. S. de; Gomes, L. P.; Costa, L. P. Estratégias de irrigação com água salina no tomateiro cereja em ambiente protegido. Revista Brasileira de Engenharia Agrícola e Ambiental, v.19, p.913-919, 2015. http://dx.doi.org/10.1590/1807-1929/agriambi. v19n10p913-919

Kong, X.; Luo, Z.; Dong, H.; Eneji, A. E.; Li, W. Effects of non-uniform root zone salinity on water use, $\mathrm{Na}^{+}$recirculation, and $\mathrm{Na}^{+}$and $\mathrm{H}^{+}$ flux in cotton. Journal of Experimental Botany, v.63, p.2105-2116, 2012. https://doi.org/10.1093/jxb/err420
Koushafar, M.; Khoshgoftarmanesh, A.; Moezzi, A.; Mobli, M. Effect of dynamic unequal distribution of salts in the root environment on performance and Crop Per Drop (CPD) of hydroponic-grown tomato. Scientia Horticulturae, v.131, p.1-5, 2011. http://dx.doi. org/10.1016/j.scienta.2011.09.016

Maas, E. V.; Hoffman, G. J. Crop salt tolerance - Current assessment. Journal of Irrigation and Drainage Division, v.103, p.115-134, 1977.

Medeiros, P. R. F. de; Duarte, S. N.; Dias, C. T. S. Tolerância da cultura do pepino à salinidade em ambiente protegido. Revista Brasileira de Engenharia Agrícola e Ambiental, v.13, p.406-410, 2009. http:// dx.doi.org/10.1590/S1415-43662009000400006

Mulholland, B. J.; Fussell, M.; Edmondson, R. N.; Taylor, A. J.; Basham, J.; McKee, J. M. T.; Parsons, N. The effect of split-root salinity stress on tomato leaf expansion, fruit yield and quality. The Journal of Horticultural Science and Biotechnology, v.77, p.509-519, 2002. http://dx.doi.org/10.1080/14620316.2002.11511531

Oliveira, F. A.; Martins, D. C.; Oliveira, M. K. T.; Souza Neta, M. L.; Ribeiro, M. S. S.; Silva, R. T. Desenvolvimento inicial de cultivares de abóboras e morangas submetidas ao estresse salino. Revista Agro@mbiente On-line, v.8, p.222-229, 2014. http://dx.doi. org/10.18227/1982-8470ragro.v8i2.1540

Peykanpour, E.; Mohammadi-Ghehsareh, A.; Fallahzade, J. Effects of water ozonated and salinity on some properties of cucumber. Journal of Agronomy, v.14, p.170-174, 2015. http://dx.doi. org/10.3923/ja.2015.170.174

Santana, M. J. de; Carvalho, J. de A.; Miguel, D. da S. Respostas de plantas de pepino à salinidade da água de irrigação. Global Science and Technology, v.3, p.94-102, 2010.

Santi, A.; Scaramuzza, W. L. M. P.; Soares, D. M. J.; Scaramuzza, J. F; Dallacort, R.; Krause, W.; Tieppo, R. C. Desempenho e orientação do crescimento do pepino japonês em ambiente protegido. Horticultura Brasileira, v.31, p.649-653, 2013. http://dx.doi. org/10.1590/S0102-05362013000400023

Shao, G. C.; Zhang, Z. Y.; Liu, N.; Yu, S. E.; Xing, W. G. Comparative effects of deficit irrigation (DI) and partial rootzone drying (PRD) on soil water distribution, water use, growth and yield in greenhouse grown hot pepper. Scientia Horticulturae, v.119, p.11-16, 2008. http://dx.doi.org/10.1016/j.scienta.2008.07.001

Sonneveld, C.; Kreij, C. Response of cucumber (Cucumis sativus L.) to an unequal distribution of salts in the root environment. Plant and Soil, v.209, p.47-56, 1999. http://dx.doi.org/10.1023/A:1004563102358

Sun, Y.; Holm, P. E.; Liu, F. Alternate partial root-zone drying irrigation improves fruit quality in tomatoes. Horticultural Science, v.41, p.185-191, 2014.

Tester, M.; Davenport, R. $\mathrm{Na}^{+}$tolerance and $\mathrm{Na}^{+}$transport in higher plants. Annals of Botany, v.91, p.503-527, 2003. http://dx.doi. org/10.1093/aob/mcg058 